\title{
PENGARUH KUANTITAS PRODUK DAN HARGA JUAL TERHADAP PENDAPATAN USAHATANI JAMUR MERANG (Studi kasus Pada Kelompok Tani Paguyuban Kaola Mandiri Di Desa Rambipuji Kecamatan Rambipuji Kabupaten Jember)
}

\author{
Fina Alfiani $^{1}$, Hety Mustika Ani ${ }^{1}$, Wiwin Hartanto ${ }^{1}$ \\ Program Studi Pendidikan Ekonomi, Fakultas Keguruan dan Ilmu Pendidikan, Universitas Jember (UNEJ) \\ Jln. Kalimantan 37, Jember 68121 \\ e-mail:140210301088@students.unej.ac.id
}

\begin{abstract}
Abstrak
Tujuan penelitian ini untuk mengetahui pengaruh yang signifikan antara kuantitas produk dan harga jual terhadap pendapatan usahatani jamur merang di Paguyuban Kaola Mandiri, dan untuk mengetahui pengaruh yang paling dominan antara kuantitas produk dan harga jual terhadap pendapatan usahatani jamur merang di Paguyuban Kaola Mandiri di Desa Rambipuji Kecamatan Rambipuji Kabupaten Jember. Penelitian ini merupakan penelitian kuantitatif dengan jumlah responden sebanyak 33 responden. Uji instrumen dalam penelitian ini yaitu uji validitas dan reliabilitas. Metode analisis data yang digunakan analisis inferensial yang terdiri dari analisis regresi linier berganda, uji asumsi klasik, analisis varian garis regresi, koefisien determinasi berganda, uji F, uji t, efektivitas garis regresi berganda, standart error of estimate. Hasil penelitian ini menunjukkan bahwa kuantitas produk dan harga jual berpengaruh signifikan terhadap pendapatan usahatani jamur merang pada kelompok tani Paguyuban Kaola Mandiri di Desa Rambipuji Kecamatan Rambipuji Kabupaten Jember sebesar 68,8\%, sedangkan 31,2\% dipengaruhi faktor lain diluar model penelitian. Sementara itu, pengaruh yang paling dominan antara kuantitas produk dan harga jual terhadap pendapatan usahatani jamur merang pada kelompok tani Paguyuban Kaola Mandiri di Desa Rambipuji Kecamatan Rambipuji Kabupaten Jember adalah kuantitas produk sebesar 58,5\%.
\end{abstract}

Kata Kunci: Kuantitas Produk, Harga jual, Pendapatan usahatani

\section{PENDAHULUAN}

Kabupaten Jember memiliki potensi yang sangat besar untuk mengembangkan budidaya jamur, khususnya yaitu jamur merang, karena bahan baku media tanam jamur merang berasal dari limbah jerami padi yang sudah tidak digunakan dan mudah dijumpai karena persediaannya yang melimpah. Mengingat Jember dikelilingi oleh areal persawahan. Sehingga, limbah tersebut dapat dimanfaatkan untuk bahan media tanam jamur merang. Usahatani jamur merang di Kabupaten Jember telah memiliki pasar yang jelas. Hampir semua petani jamur merang memiliki hubungan dengan pedagang yang siap menerima hasil produksi jamur merang dari petani dengan harga yang cukup tinggi dibandingkan tanaman sayuran lainnya. Selain itu, dengan adanya kelompok tani, para petani akan terbantu dalam hal memasarkan produksi jamur yang telah dihasilkan. Salah satu kelompok tani jamur merang yang ada di Kabupaten Jember yaitu Paguyuban Kaola Mandiri yang berlokasi di Desa Rambipuji.

Kuantitas produk yang dihasilkan di Paguyuban Kaola Mandiri akan berpengaruh pada pendapatan kotor (penerimaan) yang akan diterima petani. Adanya usaha tani jamur merang yang dilakukan para petani yang tergabung dalam Paguyuban Kaola Mandiri di Desa Rambipuji, akan membantu para petani untuk memasarkan produk jamur merang yang dihasilkan. Semakin tinggi tingkat produk yang dihasilkan petani, maka pendapatan kotor (penerimaan) juga akan meningkat, sehingga dapat memberikan pendapatan yang maksimal dari usaha tani jamur merang tersebut. Hal ini sesuai dengan pendapat Suratiyah (2015: 08) yang memaparkan melalui produksi pertanian yang berlebih maka diharapkan memperoleh pendapatan tinggi. Dengan demikian, jika produk yang dihasilkan tinggi, akan mempengaruhi pendapatan yang diterima oleh petani.

Petani tertarik untuk membudidayakan usaha tani jamur merang karena harga jamur relatif stabil dan tergolong tinggi jika dibandingkan jenis sayuran lainnya. Hal ini sesuai dengan pendapat Suharjo (2010: 38) yang menyatakan bahwa jamur merang tergolong jamur konsumsi yang harga jualnya relatif stabil daripada harga jamur konsumsi lainnya. Bahkan, harga jamur merang diperkirakan akan terus naik seiring dengan meningkatnya permintaan. Harga jual jamur merang cenderung naik dari tahun ke tahun. Berdasarkan observasi 
awal yang dilakukan di Paguyuban Kaola Mandiri, harga jamur merang di Paguyuban tersebut sudah disesuaikan dengan harga yang berlaku di tingkat petani, yaitu untuk harga di tingkat pengepul atau paguyuban itu sendiri yaitu Rp 15.000 - Rp 16.000/Kg, Harga tersebut sudah disesuaikan dengan harga pasar maupun biaya produksi yang digunakan untuk budidaya jamur merang. Namun, bukan tidak mungkin jika harga jamur merang nantinya akan mengalami kenaikan.

Berdasarkan hasil wawancara dengan salah satu petani jamur yang tergabung dalam Paguyuban tersebut, Petani jamur tidak membutuhkan lahan yang luas untuk budidaya jamur merang, karena budidaya jamur merang dapat dilakukan di dalam kumbung dengan rak bersusun. Petani jamur dengan 3 kumbung yang memiliki total luas kumbung sekitar $180 \mathrm{~m} 2$ dalam satu kali masa panen dapat menghasilkan produksi sebanyak $200 \mathrm{Kg}$ bahkan lebih jika hasil panen baik. Jika produk yang dihasilkan sekitar $200 \mathrm{Kg}$, petani akan memperoleh pendapatan kotor sebesar Rp 3.000.000 bahkan lebih sebelum dikurangi dengan biaya-biaya produksi dalam satu kali proses produksi (panen). Namun, pendapatan yang mereka terima sangat variatif dan tidak menentu. Dengan luas tanam yang dimiliki, petani berharap kuantitas produk yang dihasilkan baik, sehingga pendapatan yang diperoleh lebih besar daripada pengeluaran atau biaya produksi.

Usahatani jamur merang akan memberikan pendapatan yang maksimal, apabila kuantitas produk jamur merang yang dihasilkan petani terus meningkat, dan harga jual jamur merang tinggi, sehingga total penerimaan (pendapatan kotor) lebih besar daripada biaya produksi yang dikeluarkan selama kegiatan produksi jamur merang berlangsung. Hal ini sesuai dengan pendapat Suratiyah (2015: 88) yang memaparkan, jika permintaan akan produksi tinggi maka harga jual di tingkat petani akan tinggi, sehingga dengan biaya yang sama petani akan memperoleh pendapatan yang maksimal.

Berdasarkan penjelasan tersebut, maka peneliti bermaksud melakukan penelitian yang bertujuan untuk mengetahui pengaruh yang signifikan kuantitas produk dan harga jual terhadap pendapatan usahatani dan variabel manakah yang memliki pengaruh dominan terhadap pendapatan usahatani jamur merang di Paguyuban Kaola Mandiri Desa Rambipuji Kecamatan Rambipuji Kabupaten Jember.

\section{METODE PENELITIAN}

Penelitian ini dilakukan dengan metode kuantitatif menggunakan analisis regresi linier berganda. Adapun metode penentuan lokasi penelitian menggunakan metode purposive area. Populasi dalam penelitian ini adalah para petani jamur merang di Paguyuban Kaola Mandiri sebanyak 33 orang. Sampel dalam penelitian ini berjumlah 33 responden dengan teknik sampling jenuh (sampling sensus) yaitu semua populasi dijadikan sampel penelitian dikarenakan jumlah populasi relatif kecil. Penentuan jumlah sampel ini mengacu pada pendapat Sugiyono (2012: 96)

Metode pengolahan data pada penelitian ini terdiri dari editing, skoring, dan tabulasi. Uji instrumen dalam penelitian ini yaitu uji validitas dan reliabilitas. Metode analisis data yang digunakan dalam penelitian ini adalah analisis inferensial yang terdiri dari persamaan regresi linier berganda, uji asumsi klasik, analisis varian garis regresi, koefisien determinasi berganda $\left(\mathrm{R}^{2}\right)$, uji $\mathrm{F}$, uji t efektivitas garis regresi berganda dan standart error of estimate.

\section{HASIL DAN PEMBAHASAN \\ Hasil Penelitian}

Hasil analisis regresi linier berganda dengan menggunakan program SPSS 22.0 for windows adalah sebagai berikut:

Tabel 1 Hasil Analisis Regresi Linier Berganda

\begin{tabular}{|c|c|c|}
\hline Variabel Penelitian & Label & Koefisien Regresi \\
\hline A & Konstanta & $-0,056$ \\
\hline $\mathrm{X}_{1}$ & Kuantitas produk & 0,575 \\
\hline $\mathrm{X}_{2}$ & Harga jual & 0,151 \\
\hline
\end{tabular}


Multiple R

Fhitung
$: 0,829$

: 33,037

Sumber: Data primer diolah (2018)

Berdasarkan data diatas, maka persamaan regresi linier berganda dalam penelitian ini adalah sebagai berikut:

$$
\operatorname{LnY}=-0,056+0,575 \mathrm{Ln} \_\mathrm{X} 1+0,151 \mathrm{Ln} \_\mathrm{X} 2+\mathrm{ei}
$$

Adapun hasil perhitungan untuk analisis varian garis regresi adalah sebagai berikut:

Tabel 2 Analisis Varian Garis Regresi

\begin{tabular}{llc}
\hline & Variabel & Multiple $\boldsymbol{R}$ \\
\hline Kuantitas Produk $\left(\mathrm{X}_{1}\right)$ & dan Harga Jual $\left(\mathrm{X}_{2}\right)$ terhadap Pendapatan & 0,829 \\
Usahatani (Y) & &
\end{tabular}

Sumber: Data primer diolah (2018)

Berdasarkan tabel 2 diatas, dapat diketahui bahwa nilai koefisien korelasinya sebesar 0,829 yang artinya bahwa kuantitas produk $\left(\mathrm{X}_{1}\right)$ dan harga jual $\left(\mathrm{X}_{2}\right)$ memiliki hubungan yang sangat kuat terhadap pendapatan usahatani jamur merang pada kelompok tani Paguyuban Kaola Mandiri di Desa Rambipuji Kecamatan Rambipuji Kabupaten Jember.

Hasil perhitungan koefisien determinasi berganda pada penelitian ini adalah sebagai berikut:

$$
\mathrm{R}_{\text {square }} \mathrm{X} 100 \%=0,688 \text { X } 100 \%=68,8 \%
$$

Dari perhitungan diatas, dapat disimpulkan bahwa besarnya persentase pengaruh kuantitas produk dan harga jual terhadap pendapatan usahatani jamur merang pada Paguyuban Kaola Mandiri di Desa Rambipuji Kecamatan Rambipuji Kabupaten Jember sebesar 68,8\%, sedangkan 31,2\% dipengaruhi faktor lain diluar model penelitian. Adapun hasil uji F pada penelitian ini adalah sebagai berikut:

Tabel 3 Rekapitulasi Uji F

\begin{tabular}{ccccc}
\hline Variabel & F $_{\text {hitung }}$ & $\mathbf{F}_{\text {tabel }}$ & a & Sig. $\mathbf{F}$ \\
\hline X terhadap Y & 33,037 & 3,316 & 0,05 &, 000 \\
\hline
\end{tabular}

Sumber: Data primer diolah (2018)

Berdasarkan tabel 3 diatas, dapat diketahui bahwa nilai $\mathrm{F}_{\text {tabel }}$ yaitu 33,037> 3,316 dengan tingkat sig. $\mathrm{F}$ $<a$ yaitu $0,000<0,05$, maka sesuai dengan kriteria pengambilan keputusan pada uji $\mathrm{F}$ ini dapat disimpulkan bahwa Ho ditolak dan Ha diterima, artinya secara simultan terdapat pengaruh yang signifikan antara kuantitas produk dan harga jual terhadap pendapatan usahatani jamur merang pada Paguyuban Kaola Mandiri di Desa Rambipuji Kecamatan Rambipuji Kabupaten Jember.

Hasil perhitungan uji t adalah sebagai berikut:

Tabel 4 Hasil Analisis Uji t

\begin{tabular}{ccccc}
\hline Variabel & $\mathbf{t}_{\text {hitung }}$ & $\mathbf{t}_{\text {tabel }}$ & Sig. & Hasil Uji \\
\hline Kuantitas Produk & 7,007 & 2,042 & 0,000 & Ho ditolak \\
Harga Jual & 2,331 & 2,042 & 0,027 & Ho ditolak \\
\hline
\end{tabular}

Sumber: Data primer diolah (2018)

Variabel kuantitas produk $\left(\mathrm{X}_{1}\right)$ diperoleh nilai $\mathrm{t}_{\text {hitung }}>\mathrm{t}_{\text {tabel }}$ yaitu 7,007 > 2,042 dan sig. $<a$ yaitu 0,000 $<0,05$, artinya kuantitas produk berpengaruh secara signifikan terhadap pendapatan usahatani jamur merang pada Paguyuban Kaola Mandiri di Desa Rambipuji Kecamatan Rambipuji Kabupaten Jember. Sedangkan untuk variabel harga jual $\left(\mathrm{X}_{2}\right)$ diperoleh nilai $t_{\text {hitung }}>t_{\text {tabel }}$ yaitu $2,331>2,331$ dan sig. $<a$ yaitu $0,027<0,05$, artinya harga jual berpengaruh signifikan terhadap pendapatan usahatani jamur merang pada Paguyuban Kaola Mandiri di Desa Rambipuji Kecamatan Rambipuji Kabupaten Jember.

Adapun uji efektivitas garis regresi berganda pada penelitian ini adalah sebagai berikut:

Tabel 5 Hasil Analisis Efektivitas Garis Regresi Berganda 


\begin{tabular}{ccc}
\hline Variabel & Zero Order & Beta \\
\hline Kuantitas Produk & 0,794 & 0,736 \\
Harga Jual & 0,420 & 0,245 \\
\hline
\end{tabular}

Sumber: Data primer diolah (2018)

a) Persentase pengaruh variabel kuantitas produk $\left(\mathrm{X}_{1}\right)$ terhadap pendapatan usahatani $(\mathrm{Y})$ yaitu zero order $\mathrm{x}$ beta $\times 100 \%=0,794 \times 0,736 \times 100 \%=58,5 \%$

b) Persentase pengaruh variabel harga jual $\left(\mathrm{X}_{2}\right)$ terhadap pendapatan usahatani $(\mathrm{Y})$ yaitu zero order $\mathrm{x}$ beta $\mathrm{x}$ $100 \%=0,420 \times 0,245 \times 100 \%=10,3 \%$

Hasil uji standart error of estimate diketahui bahwa nilainya adalah sebesar 0,15614 artinya bahwa variabel terikat yaitu pendapatan usahatani tidak hanya dipengaruhi oleh kuantitas produk dan harga jual saja, melainkan juga dipengaruhi oleh variabel-variabel lain yang tidak diteliti pada penelitian ini yaitu biaya usahatani, modal, tenaga kerja, dan lainnya.

\section{Pembahasan}

Berdasarkan penelitian yang telah dilakukan oleh peneliti dapat diketahui bahwa variabel-variabel bebas pada penelitian ini yaitu kuantitas produk $\left(\mathrm{X}_{1}\right)$ dan harga jual $\left(\mathrm{X}_{2}\right)$ berpengaruh secara signifikan terhadap pendapatan usahatani (Y) pada Paguyuban Kaola Mandiri Desa Rambipuji Kecamatan Rambipuji Kabupaten Jember sebesar 68,8\% sedangkan sisanya 31,2\% dipengaruhi oleh faktor lain diluar model penelitian. Hal ini sesuai dengan pendapat Suratiyah (2015: 87) yang menyatakan bahwa faktor - faktor lain yang mempengaruhi pendapatan usahatani adalah modal, tenaga kerja, biaya usahatani, dan lainnya.

Tujuan utama petani dalam melakukan kegiatan usahatani, adalah untuk memperoleh pendapatan yang tinggi dari hasil penjualan produksi dengan harapan pendapatan yang diperoleh lebih besar daripada biaya produksi yang dikeluarkan. Dalam hal ini, petani jamur merang harus dapat menekan biaya produksi untuk memperoleh pendapatan yang maksimal. Menurut Mubyarto (dalam Isnanda 2017) menjelaskan bahwa petani akan memperhitungkan dan membandingkan antara penerimaan dan biaya, dimana semakin tinggi rasio perbandingan ini maka usaha yang dilaksanakan semakin menguntungkan. Hal ini juga sejalan dengan pendapat Fatoni (2014: 51) yang memaparkan bahwa, setiap usaha yang dilakukan diharapkan memperoleh pendapatan dari hasil penjualan melebihi biaya operasional yang dikeluarkan.

Kuantitas produk berpengaruh terhadap pendapatan usahatani karena jamur merang dapat dipanen setiap bulannya, dan bukan merupakan sayuran musiman. Produksi jamur merang dilakukan di dalam kumbung yang dapat menjaga suhu kelembapan jamur. Selain itu, petani jamur juga dimudahkan dengan tersedianya bahan baku tanam jamur yaitu jerami (merang) padi wilayah Jember, mengingat Kabupaten Jember dikelilingi areal persawahan yang luas, sehingga produksi jamur dapat dilakukan setiap bulannya.

Kuantitas produk yang dihasilkan petani dalam hal ini yaitu petani yang tergabung menjadi anggota di paguyuban tersebut, sangatlah beragam dan bervariasi, karena antara petani yang satu dengan petani yang lainnya memiliki skala usaha yang berbeda - beda yaitu mulai dari kepemilikan kumbung, sarana produksi (modal) yang digunakan, penggunaan tenaga kerja, dan lain sebagainya. Dalam penelitian ini, kuantitas produk yang dimaksud adalah jumlah produk yang dihasilkan pada satu kali masa panen, yaitu akumulasi panen pada hari pertama panen sampai hari terakhir panen, biasanya jamur dapat dipanen dari hari ke 11 sampai hari ke 30 bahkan lebih jika kondisi cuaca mendukung dan hasil panen secara kontinyu bagus, sehingga jamur dapat tumbuh dengan baik.

Pengaruh kuantitas produk memiliki pengaruh dominan sebesar 58,5\% dan memiliki hubungan yang positif terhadap pendapatan usahatani, karena jika output yang dihasilkan tinggi, maka pendapatan petani juga mengalami peningkatan. Kuantitas produk berpengaruh dominan terhadap pendapatan usahatani, karena Hal ini juga sejalan dengan pendapat Suratiyah (2015: 87) bahwa salah satu faktor yang mempengaruhi pendapatan usahatani adalah Output atau kuantitas produk jamur merang, yaitu melalui produksi pertanian yang berlebih maka diharapkan memperoleh pendapatan yang tinggi. 
Selain kuantitas produk, variabel lain yang mempengaruhi pendapatan usahatani yang dilakukan di Paguyuban Kaola Mandiri yang berlokasi di Desa Rambipuji Kecamatan Rambipuji Kabupaten Jember adalah harga jual. Harga jual jamur merang yang berlaku di tingkat petani berkisar antara Rp 15.000 - Rp 16.000. Kisaran harga diberlakukan karena dilihat dari kualitas jamur merang tiap petani yang berbeda saat panen dilakukan. Harga jual jamur merang tergolong tinggi, jika dibandingkan dengan jenis sayuran lainnya. Hal ini dikarenakan jamur merang bukan merupakan sayuran yang bersifat musiman, produksi jamur merang dilakukan di dalam kumbung, sehingga dalam kondisi cuaca apapun, petani tetap dapat melakukan kegiatan produksi. Selain itu, jamur merang juga menjadi pilihan konsumsi konsumen, karena dapat diolah menjadi berbagai macam olahan masakan dan memiliki kandungan protein, kalsium dan fosfor yang cukup tinggi.

Harga jual berpengaruh terhadap pendapatan usahatani di Paguyuban Kaola Mandiri. Namun, berdasarkan hasil analisis yang dilakukan, harga jual hanya berkontribusi sebesar 10,3\% terhadap pendapatan usahatani jamur merang di Paguyuban Kaola Mandiri, karena kisaran harga yang berlaku tidak terlalu berbeda jauh. Selain itu, harga jual jamur merang juga tergolong stabil meskipun saat terjadi kelebihan produksi dan harga jual jamur merang cenderung naik dari tahun ke tahun. Hal tersebut dapat diketahui dari hasil wawancara dengan ketua Paguyuban Kaola Mandiri yang menjadi responden dalam penelitian ini

"Lebih banyak produksi lebih bagus mbak. Kalau harga jamur merang tetap stabil meskipun kelebihan produksi. Karena disini juga sudah banyak pedagang yang ambil. Bahkan, seringkali pedagang kehabisan stok jamur merangnya. Toh, kalau jamurnya lebih, kan kita juga masih ada solusi, contohnya jamur merang kita kirim ke perusahaan untuk di blanching. Nah, itu kan tidak harus menjatuhkan harga" (R, 50).

Hal ini juga sejalan dengan pendapat Suharjo (2010: 38) yang menyatakan bahwa harga jual jamur merang tergolong stabil, bahkan cenderung naik dari tahun ke tahun. Hal lain yang perlu diperhatikan adalah petani jamur harus mampu menentukan sendiri berapa harga jual, terlebih jika petani tersebut tergabung dalam kelompok tani. Pada dasarnya, keberadaan kelompok tani dapat memperkuat posisi tawar dalam menentukan harga jual jamur merang. Menentukan harga jual akan menentukan seberapa besar keuntungan yang akan diperoleh petani. Sementara menurut pendapat dari Case \& Fair (2006: 49) harga jual akan menentukan dan mengukur berapa pendapatan yang akan diterima. Hal ini menandakan bahwa semakin tinggi tingkat harga, maka akan semakin bagus pengaruhnya terhadap pendapatan bersih yang diterima petani jamur merang.

\section{PENUTUP}

Berdasarkan hasil penelitian dan pembahasan yang telah dilakukan, maka dapat diambil kesimpulan bahwa ada pengaruh yang signifikan kuantitas produk dan harga terhadap pendapatan usahatani jamur merang di Paguyuban Kaola Mandiri Desa Rambipuji Kecamatan Rambipuji Kabupaten Jember sebesar 68,8\%, sedangkan sisanya 31,2\% dipengaruhi oleh variabel lain di luar model penelitian, seperti biaya usahatani, modal, tenaga kerja, dan lainnya. sedangkan variabel yang memiliki pengaruh dominan terhadap pendapatan usahatani jamur merang di Paguyuban Kaola Mandiri adalah kuantitas produk sebesar 58,5\%, sedangkan harga jual berkontribusi sebesar 10,3\%, hal ini terjadi karena harga jual jamur merang tergolong stabil jika dibandingkan jenis sayuran lainnya, meskipun terjadi kelebihan produksi.

Berdasarkan hasil penelitian, maka dapat diberikan saran pada petani jamur di Paguyuban Kaola Mandiri, yaitu diharapkan dapat meningkatkan kuantitas produknya dengan cara memperhatikan lingkungan kumbung agar jamur dapat tumbuh dengan baik dan subur, mengelola sarana produksi dengan baik, dan memperhatikan biaya produksi yang dikeluarkan agar pendapatan usahatani lebih besar daripada biaya produksi yang dikeluarkan. Bagi peneliti lain, hendaknya mempertimbangkan sumbangan pengaruh variabel lain yang tidak diteliti dalam penelitian ini. Peneliti yang melakukan penelitian serupa, dapat dikembangkan dengan menambah variasi variabel, dan menambah jumlah responden agar dapat mewakili masyarakat luas

\section{DAFTAR PUSTAKA}

Case \& Fair. 2006. Prinsip - Prinsip Ekonomi. Jakarta: Erlangga 
Isnanda, N. 2017. Pengaruh Biaya Usahatani Buah Naga Terhadap Keuntungan Para Petani Buah Naga di Desa Temurejo Kecamatan Bangorejo Kabupaten Banyuwangi. Jurnal Vol. 11 No. 1. Universitas Jember

Sugiyono. 2012. Metode Penelitian Kuantitatif Kualitatif \& RND. Bandung: Alfabeta

Suharjo, Enjo. 2010. Bertanam jamur merang. Jakarta: PT. Agromedia Pustaka.

Suratiyah, Ken. 2015. Ilmu Usahatani. Jakarta Timur: PT. Penebar Swadaya 